\title{
16. MAGNETOSTRATIGRAPHY OF SEDIMENTS FROM SITES 748 AND 750, LEG $120^{1}$
}

\author{
Hiroo Inokuchi ${ }^{2}$ and Franz Heider ${ }^{3}$
}

\begin{abstract}
The magnetostratigraphy of Sites 748 and 750 of Ocean Drilling Program Leg 120 is reported. About 260 sediment cubes were stepwise demagnetized with alternating fields to determine their characteristic direction of natural remanent magnetization. In general, the characteristic inclinations of the single samples have values similar to the inclination values obtained from whole-core measurements at the nearest depth. The preliminary magnetostratigraphy of Sites 748 and 750 , which had been reported based on shipboard measurements, was confirmed and extended. A rather complete magnetostratigraphic record from the middle Eocene to the Pliocene was obtained from Site 748 .
\end{abstract}

\section{INTRODUCTION}

One of the objectives of Ocean Drilling Program (ODP) Leg 120 was to study the Late Cretaceous to Holocene paleoceanic history of the southern Indian Ocean. The magnetostratigraphy of the sedimentary cores recovered from the Kerguelen Plateau was investigated to help date the biostratigraphic events more accurately. The results of this paper will contribute to a combined magnetobiostratigraphy study in high southern latitudes (Harwood et al., this volume). Paleomagnetic results from single sediment samples of undisturbed core segments from Sites 748 and 750 are presented in this paper, whereas results from Sites 747,749 , and 750 are described elsewhere (Heider et al., this volume). The sediment cores discussed here were recovered with the advanced hydraulic piston corer (APC), the extended core barrel (XCB), and the rotary core barrel (RCB).

Sites 748 and 750 are located on the Southern Kerguelen Plateau in the western part of the Raggatt Basin, east of Banzare Bank ( $58^{\circ} 26.45^{\prime} \mathrm{S}, 78^{\circ} 58.89^{\prime} \mathrm{E}, 1291 \mathrm{~m}$ water depth), and on the Southern Kerguelen Plateau in the eastern part of the Raggatt Basin, west of the deep Labuan Basin $\left(57^{\circ} 35.54^{\prime} \mathrm{S}, 81^{\circ} 14.42^{\prime} \mathrm{E}\right.$, $2031 \mathrm{~m}$ water depth), respectively. The $100 \%$ APC and XCB core recovery in the upper $180 \mathrm{~m}$ of the section in Hole 748B provided an excellent Pleistocene to middle Eocene calcareousbiosiliceous section, which extends from lithologic Unit I to the upper part of Unit II (i.e., Pliocene/Pleistocene diatom ooze and upper Miocene to middle Eocene nannofossil ooze). From Hole $750 \mathrm{~A}$, Paleocene to Maestrichtian nannofossil chalks were recovered between 300 and $400 \mathrm{~m}$ below seafloor (mbsf). These cores were not continuous, but they are useful for paleomagnetic work. This section extends from the lower part of lithologic Subunit IIB to the upper part of Subunit IIIA.

A preliminary magnetostratigraphy was determined during the cruise (Schlich, Wise, et al., 1989, "Paleomagnetic" sections, "Site 748" and "Site 750" chapters). The shipboard paleomagnetic measurements were conducted with the pass-

\footnotetext{
${ }^{1}$ Wise, S. W., Jr., Schlich, R., et al., 1992. Proc. ODP, Sci. Results, 120: College Station, TX (Ocean Drilling Program).

2 Department of Earth Sciences, Faculty of Science, Kobe University, Kobe 657, Japan (present address: Marine Biological Station, Faculty of Science, Kobe University, Iwaya 2746, Awaji, Tsuna, Hyogo 656-24, Japan).

${ }^{3}$ Geophysics Laboratory, Department of Physics, University of Toronto, Toronto, Ontario, M5S 1A7, Canada (current address: Institüt für Allgemeine und Angewandte Geophysik, Ludwig-Maximilians-Universităt, Theresienstrasse 41, 8000 München 2, Federal Republic of Germany).
}

through cryogenic magnetometer onboard the JOIDES Resolution using the $1.5-\mathrm{m}$-long archive halves of the cores. Inclination, relative declination, and intensity of magnetization values were obtained from all undisturbed cores. The magnetostratigraphic results could be correlated to the standard magnetic polarity reversal sequence after an overprint had been removed by a $9-\mathrm{mT}$ alternating field (AF). Whether the 9-mT AF demagnetization was sufficient to determine characteristic directions remained to be determined from single specimens. The validity of the shipboard preliminary magnetostratigraphy has been tested, and some gaps that existed in the previous record have been filled.

\section{PALEOMAGNETIC MEASUREMENTS}

More than 260 soft sediment samples from Cores 120 $748 \mathrm{~A}-1 \mathrm{H},-2 \mathrm{H}, 120-748 \mathrm{~B}-2 \mathrm{H}$ through $-20 \mathrm{H}, 120-750 \mathrm{~A}-13 \mathrm{R}$, $120-750 \mathrm{~A}-14 \mathrm{R}$, and $120-750 \mathrm{~A}-16 \mathrm{R}$ through $-22 \mathrm{R}$ were taken during the cruise with oriented ODP plastic cubes $\left(7 \mathrm{~cm}^{3}\right)$. Two samples per $1.5-\mathrm{m}$ section of the core were taken on average when the sediment was not disturbed. Cubes with arrows in the upcore direction were pressed into the sampling half of the core. Harder samples were precut with a sharp knife before collection with the sampling cubes.

The paleomagnetic measurements were conducted in the paleomagnetism laboratory at Kobe University with a SCT two-axis cryogenic magnetometer. It was difficult to measure magnetic moments weaker than $1 \times 10^{-10} \mathrm{Am}^{2}$ because the cryogenic magnetometer had a maximum sensitivity of $1 \times$ $10^{-11} \mathrm{Am}^{3}$.

Pilot samples were stepwise-AF demagnetized up to $60 \mathrm{mT}$ with a tumbling AF demagnetizer. The remaining samples were stepwise-AF demagnetized with at least four steps up to $40 \mathrm{mT}$ to obtain their characteristic remanence components. Results from samples with stable inclination were used for magnetostratigraphy (Figs. 1A and 1B). Samples with low intensity of magnetization or with unstable magnetization in which directions changed significantly between demagnetization steps (Fig. 1C) were not considered for magnetostratigraphy. Characteristic remanence directions could be determined from about $80 \%$ of the samples.

The characteristic direction of each sample was determined from a straight-line segment of the stepwise AF demagnetization data plotted on an orthogonal vector projection (Zijderveld diagram) (Zijderveld, 1967). The declinations of the samples have no meaning as the cores were not oriented with respect to azimuth. Thus, only inclination data will be discussed in this paper. 
A.
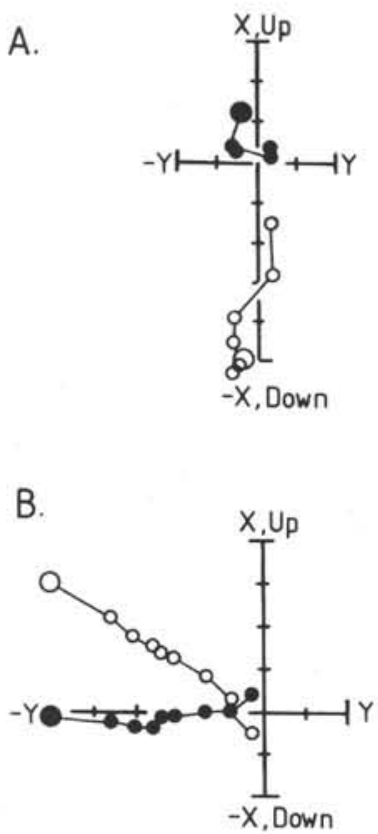

C.

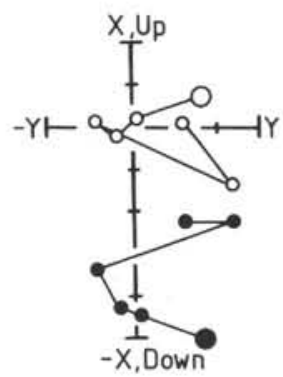

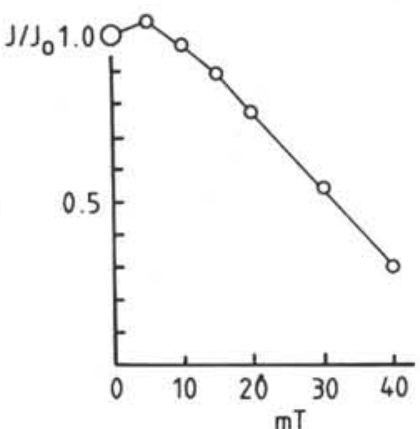
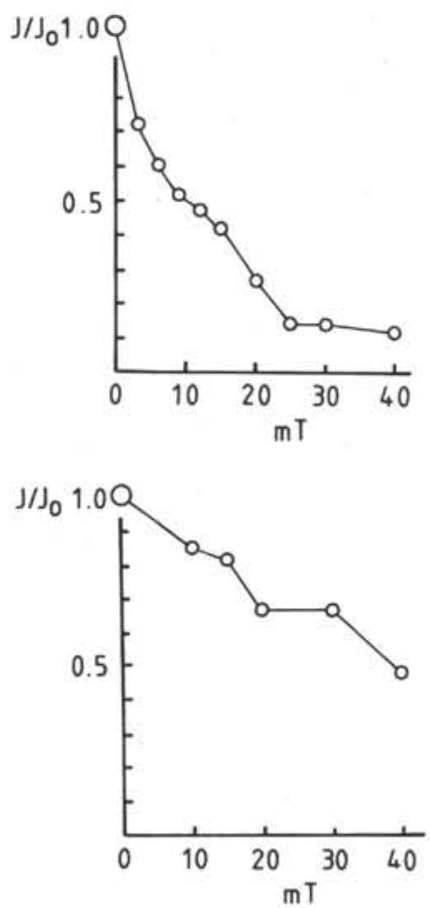

Figure 1. Examples of stepwise alternating-field demagnetization of natural remanent magnetization. Changes in direction during demagnetization are presented in orthogonal vector projections (left, Zijderveld diagram), and the decay of the normalized intensity is plotted as a function of the peak intensity of the alternating field (right). Solid and open circles represent horizontal ( $\mathrm{X}$ and $\mathrm{Y}$ ) and vertical (upward-downward and $\mathrm{X}$ ) components of magnetization, respectively. A. Sample 120-748B-2H-7, 32-34 cm, with negative characteristic inclination (normal polarity). B. Sample 120-748B$3 \mathrm{H}-5,32-34 \mathrm{~cm}$, with positive inclination. C. Sample 120-748B-4H-4, $32-34 \mathrm{~cm}$, with unstable magnetization.

In most cases, the straight-line segment through the AF demagnetization data in the orthogonal vector projection included the $10-\mathrm{mT}$ data point. The inclination values from single sample measurements are similar to the inclination values at equivalent depths after 9-mT AF demagnetization on the ship. Therefore, the demagnetizing field during the shipboard measurements was suitable to obtain the characteristic inclinations in most cases. Even when the inclination value from a single sample was not similar to that from the wholecore measurements on the ship, both results show the same polarities (i.e., signs of inclination). For a few samples, the results from single specimens do not agree with whole-core measurements. The results from single sample measurements are considered to be more reliable because each measurement was based on at least four steps of AF demagnetization and high-coercivity components were isolated.

It was generally observed that single samples from parts of the core that were too weakly magnetized to be measured with the shipboard pass-through magnetometer were also too weakly magnetized for land-based measurements. The higher sensitivity of the land-based magnetometer is offset by the smaller volume of the single sample compared with the larger volume of the split halves of the cores on the JOIDES Resolution.

\section{MAGNETOSTRATIGRAPHY}

The magnetostratigraphic records determined from the shipboard inclination data and the characteristic inclinations 
of the single-sample cubes are shown in Figures 2 and 3 . Negative inclinations correspond to normal polarity of the geomagnetic field and positive inclinations to reversed polarity. The inclination data from the single samples confirmed the results obtained during the cruise, in most cases. An interpretation of the inclination data in terms of normal and reversed polarity is shown in black and white in the right-hand column of Figures 2 and 3. Specific magnetic polarity chrons could be identified by correlation with the standard geomagnetic time scale (Berggren et al., 1985; Kent and Gradstein, 1985) using the available paleontological data (Harwood et al., this volume; Wei et al., this volume).

\section{Site 748}

Previously, the top of magnetic Subchron 2A (Gauss normal polarity chron) was thought to be at 3.25 mbsf. Sample $120-748 \mathrm{~B}-2 \mathrm{H}-2,112-114 \mathrm{~cm}$, has a negative inclination in contrast to the positive inclinations recorded during shipboard measurements. The top of Subchron 2A, therefore, extends up to 2.7 mbsf. The bottom of Subchron $2 \mathrm{~A}$ occurs at 6.9 mbsf. No inconsistency between the single-sample and the whole-core measurements exists around the bottom of Subchron 2A. Below Subchron 2A, reversed polarity was confirmed by the single-sample measurements.

The subsequent normal chrons with short reversed subchrons appear to correspond to Subchrons $3 A$ and $4 A$ and Chron 4. A data gap and/or a short hiatus probably hides Chron 3. A short reversed epoch at 14.8 mbsf could correspond to the short reversed event in Subchron 3A. Chron 5 to Subchron 5B were not observed because of a data gap and uninterpretable data as well as a hiatus which was inferred from the sedimentation rate curve.

Subchrons $5 \mathrm{C}-6 \mathrm{C}$ can be identified between 34 and 68 mbsf. Subchron $5 \mathrm{C}$ could not be identified from the shipboard measurements, but it was found during land-based measurements of the three single samples. The top and bottom of Subchron 5CN occur at about 35 and 38 mbsf, respectively. Subchron 5DN was confirmed from the three single-sample results. Reversed Subchrons 5BR, 5CR, and 5DR were also confirmed or were found by single-sample measurements, as shown in Figure 2. Normal Subchrons 5E and/or Chron 6 was detected between 46.6 and 53.6 mbsf. A reversed interval between Subchrons $5 \mathrm{EN}$ and $6 \mathrm{~N}$ was not identified from the single-sample measurements. The sequence of Subchrons 6A, $6 \mathrm{AA}, 6 \mathrm{~B}$, and $6 \mathrm{C}$ was also confirmed by the land-based investigation. The three normal subchrons of $6 \mathrm{C}$ at the boundary between the Miocene and Oligocene were easily recognized between 65 and 68 mbsf.

Below a hiatus of approximately $2 \mathrm{~m} . \mathrm{y}$. , which was determined by the sedimentation rate data at $69.5 \mathrm{mbsf}$ (Schlich, Wise, et al., 1989), part of Chron 7 was identified at 70 mbsf. A possible corrected interpretation of Subchron 7A through Chron 12 is shown in Figure 2. This sequence was slightly modified by the land-based measurements.

Reversed polarity was found at about 96 mbsf in two single samples, which may.correlate to reversed Subchron 11R. A long reversed interval between normal Subchrons $12 \mathrm{~N}$ and $13 \mathrm{~N}$ was identified between 105 and 113 mbsf with some certainty. The existence of Chron 13 at 115 mbsf was suggested by the study of calcareous nannofossils (Wei et al., this volume). Two short normal events at 106 and at 112 mbsfreported on board-were changed to reversed polarity based on the single-sample measurements.

Below $120 \mathrm{mbsf}$, the intensities of the magnetization becomes too weak to draw reliable conclusions. Possible occurrences of normal Subchrons $16 \mathrm{~N}$ and $17 \mathrm{~N}$ at 130 and 150 mbsf were confirmed by single-sample measurements.
Below the normal interval between 163 and 167 mbsf indicated by the shipboard measurements, a subsequent normal and reversed polarity sequence was identified at about 171 through 177 mbsf using single-sample measurements. This normal sequence between 171 and 175 mbsf may be correlated to Subchron $18 \mathrm{~N}$ as suggested by paleontologic data (Wei et al., this volume).

\section{Site 750}

At Hole $750 \mathrm{~A}$, continuous coring was used to recover Cores 120-750A-10R to -20R. These 11 cores (298-404 mbsf) were recovered with about $50 \%$ average recovery rate, and there is no continuous magnetostratigraphic record. The identification of normal and reversed polarities requires additional information from biostratigraphic data. The normal polarity segment in Core 120-750A-12R (around 320 mbsf) was interpreted as the lower part of normal Subchron $27 \mathrm{~N}$ in the early Paleocene. The normal period in Core 120-750A-14R (about 339 mbsf) occurred where Subchron $28 \mathrm{~N}$ would fall, based on paleontologic evidence; this was confirmed by two single-sample measurements. The reversed polarity epoch in Core 120-750A-15R between 346.3 and 350.3 mbsf can be identified as Subchron 29R, which contains the Cretaceous/Tertiary boundary (Schlich, Wise, et al., 1989). We located the reversed polarity at $\sim 355$ mbsf in four single samples from Core $120-750 \mathrm{~A}-16 \mathrm{R}$, as well as a normal period at about $375 \mathrm{mbsf}$ in three single samples from Core $120-750 \mathrm{~A}-18 \mathrm{R}$. The reversed and normal sequence of Core 120-750A-17R below 365 mbsf was confirmed by five single samples. Paleomagnetic results from Cores 120-750A$19 \mathrm{R}$ and $-20 \mathrm{R}$ were confirmed or extended by land-based observations, as shown in Figure 3. Two normal polarity points were found at about $405 \mathrm{mbsf}$. The sequence between 364 and 405 mbsf may be tentatively correlated to Chrons 30 through 32 .

\section{CONCLUSIONS}

The magnetostratigraphy of sediments from Sites 748 and 750 determined on board with the pass-through cryogenic magnetometer was confirmed, in general, by our land-based investigation on single samples. Occasionally, the preliminary magnetostratigraphy was modified based on single-sample measurements. At Site 748 a good paleomagnetic sequence was obtained containing Subchrons $2 \mathrm{~A}$ and $3 \mathrm{~A} / 4 \mathrm{~A}$ and Subchron $5 \mathrm{C}$ through Chron 13 , as well as part of the sequence from Chrons 16 to 18 , with the identification of at least two hiatuses. An excellent and continuous paleomagnetic record was observed between 35 and 120 mbsf corresponding to the interval from the early Miocene to the Oligocene (Subchron $5 \mathrm{C}$ through Chron 13). At Site 750, an incomplete paleomagnetic sequence between 300 and 405 mbsf probably corresponds to Chrons 27 to 32 . A more complete magnetostratigraphy for these high southern latitudes will be obtained by combining the records reported here with those from Sites 747,749 , and 751 reported by Heider et al. (this volume). Furthermore, cross-correlation between the magnetostratigraphy and biostratigraphy should yield a good combined biomagnetostratigraphy from the Neogene to the Upper Cretaceous for these latitudes.

\section{ACKNOWLEDGMENTS}

Discussions with Sherwood W. Wise, Jr., and William A. Berggren, and their comments to the paper were highly appreciated. Critical reviews by C. Klootwijk and K. Verosub are also appreciated. We thank the Ocean Research Institute, the University of Tokyo, and the Ocean Drilling Program for the opportunities to participate on Leg 120. 


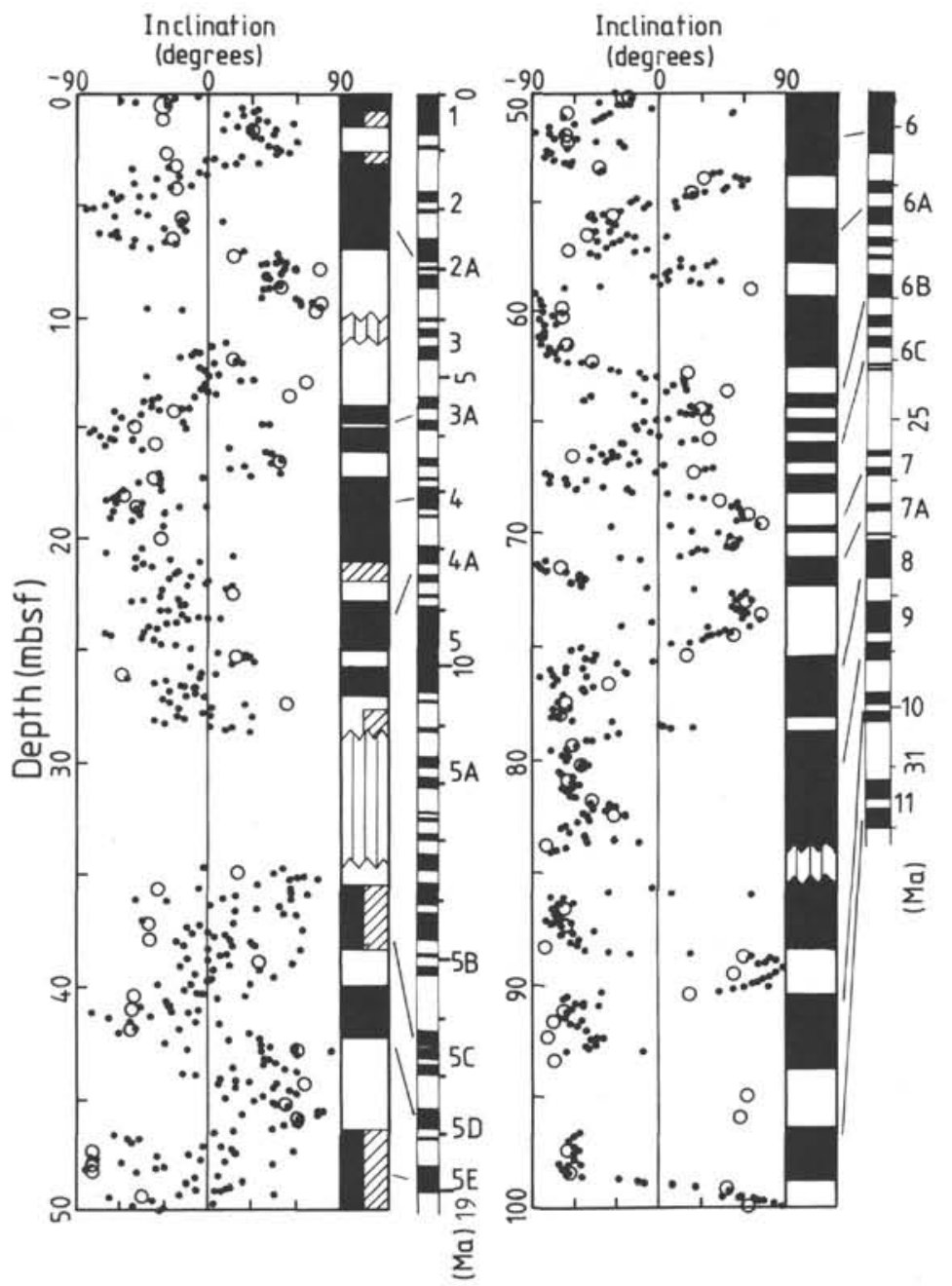

Figure 2. Inclinations and magnetic polarity reversals from Hole $748 \mathrm{~B}(0-180$ mbsf) are plotted vs. depth. Inclinations from whole-core measurements and from single samples are represented in the left-hand column by black dots and open circles, respectively. An interpretation of the inclination record in terms of the magnetic polarity reversals is presented in the middle column. Black = normal polarity, white $=$ reversed polarity, diagonal stripes $=$ uninterpretable data, and vertical stripes = lack of data. The standard magnetic time scale (Berggren et al., 1985) is represented in the right-hand column.

\section{REFERENCES}

Berggren, W. A., Kent, D. V., Flynn, J. J., and Van Couvering, J. A., 1985. Cenozoic geochronology. Geol. Soc. Am. Bull., 96:1407-1418.

Kent, D. V., and Gradstein, F. M., 1985. A Cretaceous and Jurassic geochronology. Geol. Soc. Am. Bull., 96:1419-1427.

Schlich, R., Wise, S. W., Jr., et al., 1989. Proc. ODP, Init. Repts., 120: College Station, TX (Ocean Drilling Program).
Zijderveld, J.D.A., 1967. AC demagnetization of rocks: analysis of results. In Collinson, D. W., Creer, K. M., and Runcorn, S. K. (Eds.), Methods in Palaeomagnetism: New York (Elsevier), 254286.

Date of initial receipt: 13 February 1990

Date of acceptance: 24 October 1990

Ms 120B-191 


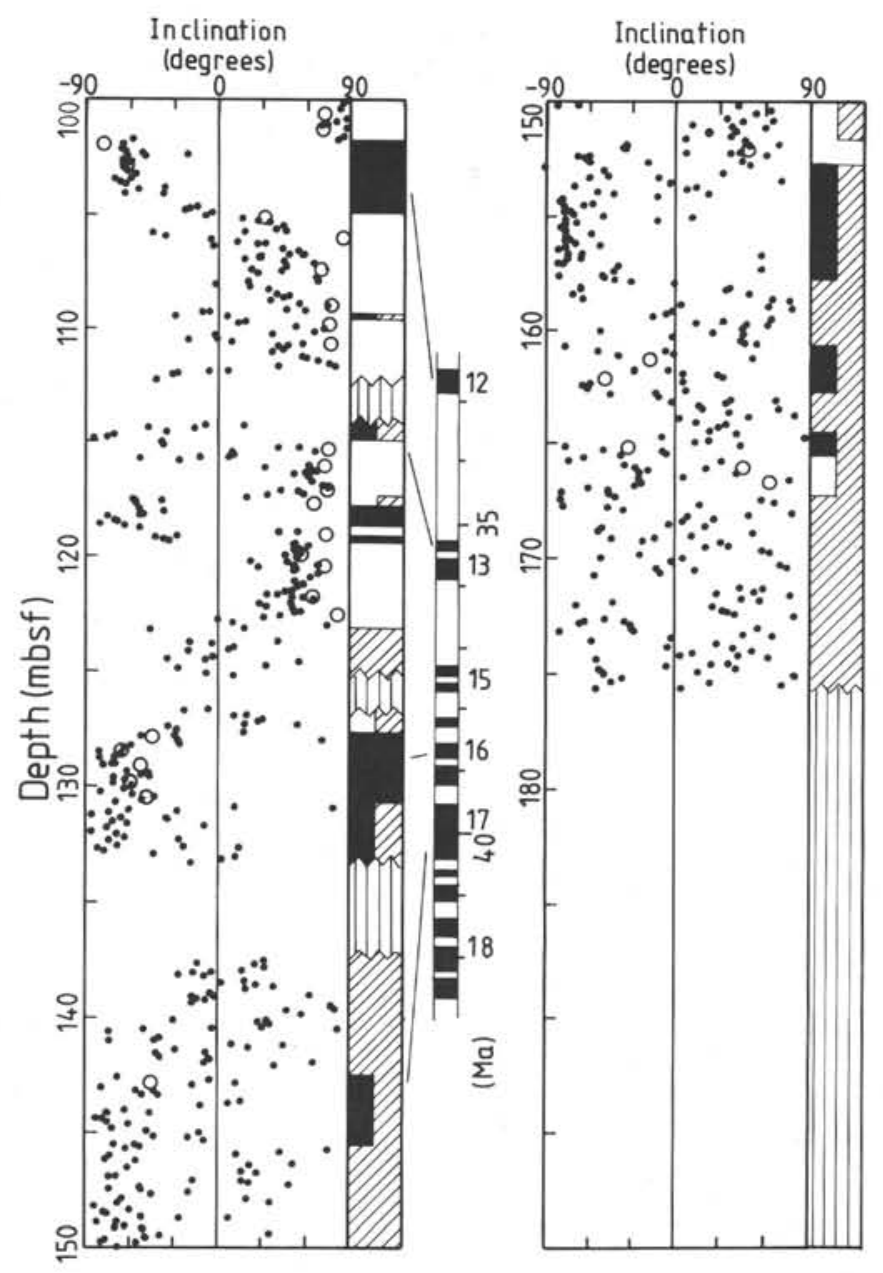

Figure 2 (continued). 


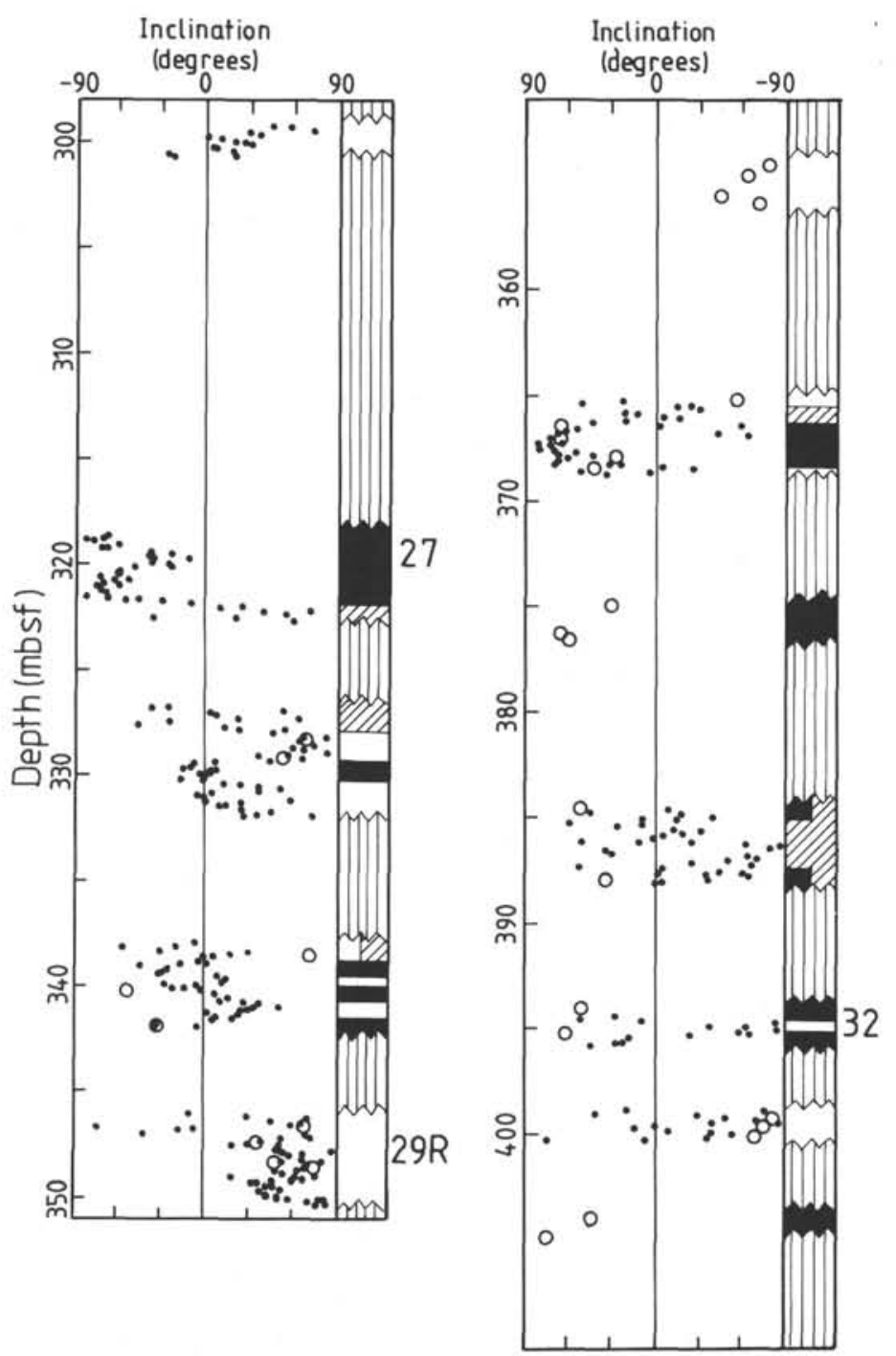

Figure 3. Inclinations and magnetic polarity reversals from Hole $750 \mathrm{~A}$ (300-410 mbsf) are plotted vs. depth. For an explanation of symbols, see Figure 2. 